\title{
Phytotherapies in motion: French Guiana as a case study for cross-cultural ethnobotanical hybridization
}

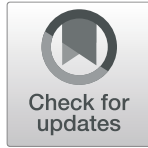

\author{
M.-A. Tareau ${ }^{1 *}\left(\mathbb{D}\right.$, A. Bonnefond ${ }^{2}$, M. Palisse ${ }^{1}$ and G. Odonne ${ }^{1}$
}

\begin{abstract}
Background: French Guiana is characterized by a very multicultural population, made up of formerly settled groups (Amerindians, Maroons, Creoles) and more recent migrants (mostly from Latin America and the Caribbean). It is the ideal place to try to understand the influence of intercultural exchanges on the composition of medicinal floras and the evolution of phytotherapies under the effect of cross-culturalism.
\end{abstract}

Methods: A combination of qualitative and quantitative methods was used. Semi-directive interviews were conducted in 12 localities of French Guiana's coast between January 2016 and June 2017, and the responses to all closed questions collected during the survey were computerized in an Excel spreadsheet to facilitate quantitative processing. Herbarium vouchers were collected and deposited at the Cayenne Herbarium to determine Linnaean names of medicinal species mentioned by the interviewees. A list of indicator species for each cultural group considered was adapted from community ecology to this ethnobiological context, according to the DufrêneLegendre model, via the "labdsv" package and the "indval" function, after performing a redundancy analysis (RDA).

Results: A total of 205 people, belonging to 15 distinct cultural groups, were interviewed using semi-structured questionnaires. A total of 356 species (for 106 botanical families) were cited. We observed that pantropical and edible species hold a special place in these pharmacopeias. If compared to previous inventories, 31 recently introduced species can be counted. Furthermore, this study shows that the majority of the plants used are not specific to a particular group but shared by many communities. However, despite this obvious cross-culturalism of medicinal plants between the different cultural communities of French Guiana, divergent trends nevertheless appear through the importance of 29 indicator/cultural keystone species in 10 cultural groups. Finally, we have emphasized that the transmission of herbal medicine's knowledge in French Guiana is mainly feminine and intracultural.

Conclusion: French Guianese medicinal flora is undoubtedly related to the multiple cultures that settled this territory through the last centuries. Cultural pharmacopeias are more hybrid than sometimes expected, but cultural keystone species nevertheless arise from a common background, allowing to understand, and define, the relationships between cultural groups.

Keywords: Cultural keystone species, Indicator species, Exchange networks, Migrations

\footnotetext{
* Correspondence: tareau.marc.alexandre@gmail.com

'LEEISA (Laboratoire Ecologie, Evolution, Interactions des Systèmes

Amazoniens), CNRS, Université de Guyane, IFREMER, 97300 Cayenne, French

Guiana

Full list of author information is available at the end of the article
}

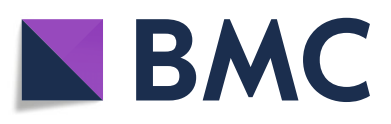

(c) The Author(s). 2020 Open Access This article is licensed under a Creative Commons Attribution 4.0 International License, which permits use, sharing, adaptation, distribution and reproduction in any medium or format, as long as you give appropriate credit to the original author(s) and the source, provide a link to the Creative Commons licence, and indicate if changes were made. The images or other third party material in this article are included in the article's Creative Commons licence, unless indicated otherwise in a credit line to the material. If material is not included in the article's Creative Commons licence and your intended use is not permitted by statutory regulation or exceeds the permitted use, you will need to obtain permission directly from the copyright holder. To view a copy of this licence, visit http://creativecommons.org/licenses/by/4.0/. The Creative Commons Public Domain Dedication waiver (http://creativecommons.org/publicdomain/zero/1.0/) applies to the data made available in this article, unless otherwise stated in a credit line to the data. 


\section{Background}

Ethnobotany of migrants is occupying an increasingly important place in modern ethnobiology, thanks to numerous recent works of ethnographic description and conceptualization of these practices [1-13], and particularly in an urban context where moving populations are often concentrated [1, 2, 5, 8-10, 14-19]. Indeed, the question of the resulting ethnobotanical hybridizations is now at the heart of interdisciplinary questioning in ethnosciences [20-25], as it is nowadays accepted that phytotherapeutical practices are dynamic cultural processes which are constantly nourished by the circulation of people and the interactions between different cultural groups.

The highly multicultural context of French Guiana is a very interesting example to study these changes on the scale of a medium-sized area. This French territory in South America (Fig. 1), after having received many cultural groups during the colonial era, is today hosting a migrant population estimated to be more than a third of the total population (https://www.insee.fr/fr/statistiques/41 77174? sommaire $=4177618$ \&geo=REG-03) counting many inhabitants originating from Haiti, Brazil, Suriname, or even the Dominican Republic and Peru, and giving rise to a fairly remarkable intercultural mix $[26,27]$.

If the vitality of herbal medicine practices among young French Guianese urban people has already been shown [16], along with the importance in this Amazonian space of the gathering of medicinal plants by several populations [17] and the circulation of medicinal plants at its borders, especially with Brazil [28], a general overview of the current phytotherapeutic uses in this territory had not been established yet. Thus, from a perspective seeking to question every cultural group present, we wanted to understand what could be the main dynamics in ethnopharmacopeias in this context of interculturality, migration, and urbanization, in order to better understand how they adapt to these social changes. Thus, the main questions that this study attempts to answer can be summarized as follows:

- Does multiculturalism, as found in French Guiana, favor the appearance of a multitude of pharmacopeias or, on the contrary, do the interactions between all these groups cause leveling of knowledge and practices?

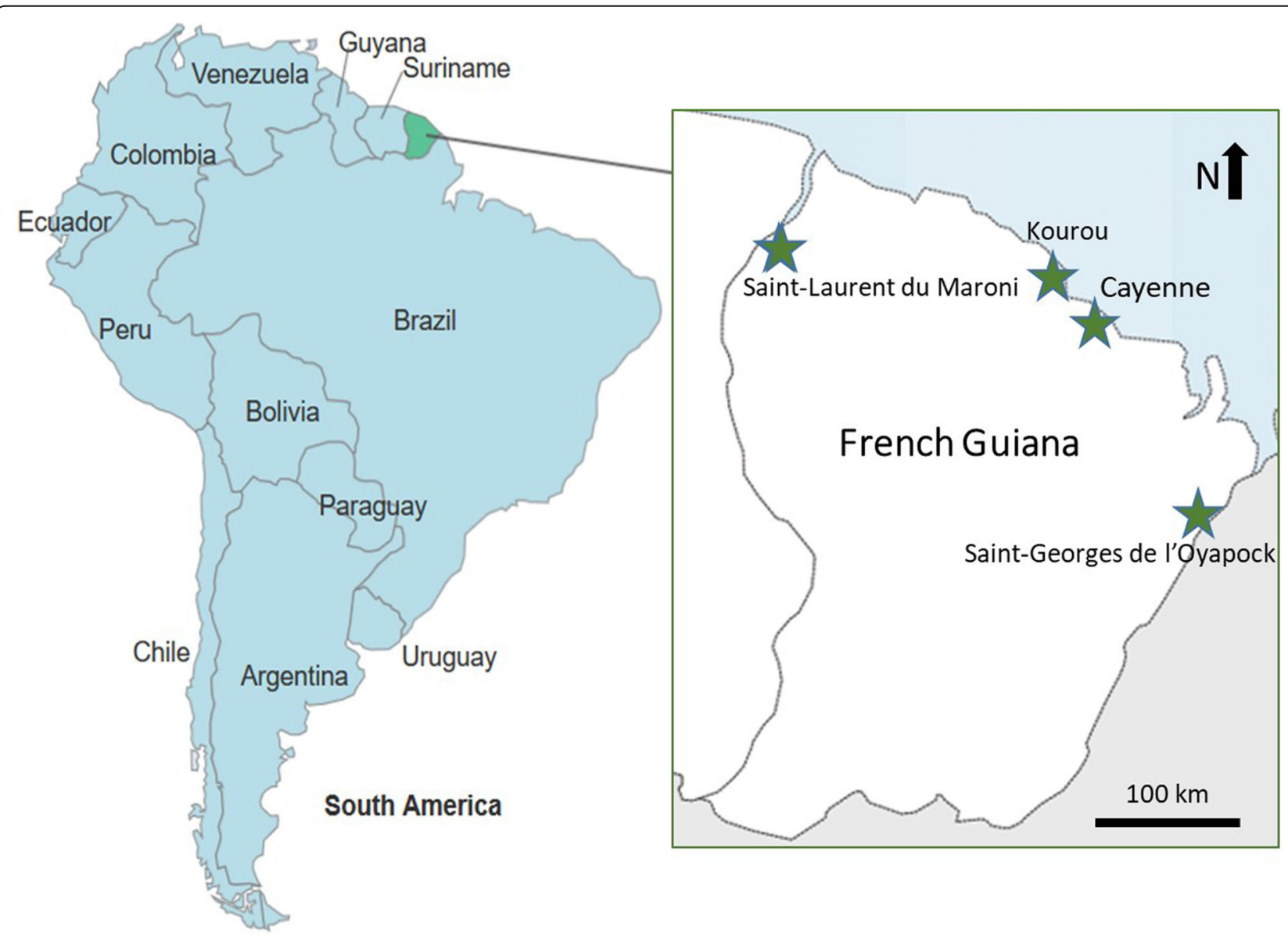

Fig. 1 Location map of French Guiana 
- Does migratory and cross-cultural context favor greater biocultural diversity? How is the distribution of medicinal flora organized according to ethnic groups, in a situation of cultural pluralism?

- How are the transmission processes shaped in these particular contexts, in terms of groups, but also in terms of individuals (sex, age)?

\section{Methods}

\section{Interviews}

The data used for this article served as the ethnographic basis for the production of Tareau's PhD thesis [29]. Interviews were realized between January 2016 and June 2017, i.e., during 18 months, over a wide strip covering the whole of the French Guiana coast (Fig. 1), comprising 12 municipalities out of the 22 municipalities of this territory. Urban people, living in the main cities of French Guiana (Cayenne, Kourou, Matoury, Rémire-Montjoly, and SaintLaurent du Maroni), were interviewed, as were non-urban dwellers living in small countryside villages.

The first people interviewed were approached informally, on the street or at their workplace. Then, by snowball sampling [30], other respondents were gradually contacted. Semi-structured interviews were conducted, detailing the profile of each person interviewed, the medicinal species they used, the culturally specific or rather shared nature of each of them, and their access strategies and transmission patterns.

\section{Prior informed consent and access to biodiversity}

Prior to the implementation of the French transcription of the Nagoya protocol, and in the absence of internal ethics committee at the Université de Guyane, we worked in accordance with the recommendations of the Code of Ethics of the International Society of Ethnobiology [31]. Informed consent forms were given to all the respondents in order to present and explain to them clearly the objectives of this research project and to obtain their signed agreement to participate. Each of the interviewees was informed beforehand of the confidentiality of this study, and of his/her right to withdraw its participation at any time, and of the objective of publication at the end under the form of a $\mathrm{PhD}$ thesis and scientific publications.

\section{Statistical analysis}

The responses to all closed questions collected during the survey were computerized in an Excel spreadsheet to facilitate quantitative processing [32], coupled with a complementary qualitative approach.

Use reports (URs), as explained by Phillips and Gentry [33], correspond to the frequency of citations of one or more species, in general or for a particular therapeutic indication. These use reports can also be converted into percentage of the total number of uses.

Community groups were defined according to the interviewee's stated language of first socialization, place of birth, and the cultural identity to which they say themselves that they primarily belong.

Statistical analyses were performed using R 3.3.3 [34] in order to explore if the composition of specific medicinal floras differed according to ethnicity. To do so, the global dataset was refined to make it suitable for statistical analyses. Community groups were restricted to those encompassing a minimum of 5 persons. To avoid introducing a bias according to the "level of knowledge" of each person interviewed on the topic, a postprocessing sorting was carried out aiming to remove people who mentioned either much more, or fewer species compared to other (species citation per person thus range from 2 to 64 species). Then, the least cited species ( $<3$ URs) were excluded, considering their uses as not representative in the overall population.

The indval function in the R package "labdsv" [35] was used to set a list of indicator species, according to the Dufrêne-Legendre model, for each cultural group considered. This method is commonly used in ecology to detect indicator species in ecosystems and was adapted here to highlight indicator species in different cultural groups. In short, this method gives a maximum index when all URs of a species are found in a single cultural group and when that species is cited by all individuals belonging to that group.

A redundancy analysis (RDA) was conducted using the "Vegan" package [36]. Abundance data were Hellinger transformed. Significance levels were set to a nominal type-I error of $5 \%$.

A food web analysis was performed to understand the plant exchanges among cultural groups. It has been made by considering the main intercultural fluxes of knowledge ( $\geq 0.5 \%$ of total URs, with $N=3592$ ) and only the groups counting for more than $1 \%$ of all the transmitted URs $(N=3592)$ were conserved in the plot.

\section{Botany}

Voucher specimens of cited plants were collected with the informants as much as possible. They were then processed and deposited at the Cayenne IRD Herbarium (CAY). Botanical determinations were performed by $\mathrm{M}$. A. Tareau and G. Odonne. The taxonomical nomenclature used was the APG IV [37].

\section{Results}

People interviewed

A total of 205 people were interviewed using semistructured questionnaires, belonging to 15 distinct cultural groups (Table 1). 
Table 1 Table presenting the number of individuals questioned by community, the number of use reports (URs) provided by group, and the average per person of each group

\begin{tabular}{llll}
\hline Cultural groups & Number & URs & URs/informant \\
\hline French Guianese Creoles & 55 & 1165 & 21.2 \\
Ndjuka & 19 & 483 & 25.4 \\
Haitians & 19 & 267 & 14.1 \\
French Caribbean Creoles & 18 & 264 & 14.7 \\
St Lucians & 18 & 541 & 30.1 \\
Palikur & 15 & 175 & 11.6 \\
Brazilians & 15 & 153 & 10.2 \\
Saamaka & 12 & 161 & 13.4 \\
Kali'na & 10 & 120 & 12.2 \\
French from mainland France & 7 & 85 & 12.1 \\
Guyanese & 4 & 56 & 14 \\
Aluku & 4 & 62 & 15.5 \\
Dominicans & 3 & 38 & 12.6 \\
Galibi-Marwono & 3 & 48 & 16 \\
Karipuna & 3 & 65 & 21.7 \\
Total & $\mathbf{2 0 5}$ & $\mathbf{3 6 8 3}$ & $\mathbf{1 7 . 6}$ \\
\hline
\end{tabular}

After refining for statistical analyses, the new dataset counts 200 interviews from 12 cultural groups: French Guianese Creoles (61 persons); Aluku, Paamaka, Ndjuka and Saamaka Maroons (33 p.); Haitians (19 p.); French Caribbean Creoles (18 p.); Brazilians (15 p.); Pahikwene (12 p.); St Lucians (11 p.); Kali'na (10 p.); Europeans (6 p.); Galibi-Marwono and Karipuna (5 p.); Guyanese (5 p.); and Peruvians and Dominicans (5 p.).

Respondents have an average age of 52.5 years. Seventy-seven people were, at the time of the survey, between 18 and 40 years old (1110 URs), 92 were between 41 and 65 years old (1521 URs), and 39 were over 65 years old (1052 URs). The sampling is constituted of $58.5 \%$ of women $(N=120 ; 2355$ URs $)$ and $41.5 \%$ of men $(N=85 ; 1328$ URs); $59.5 \%$ are considered urbans $(N=122 ; 2101 \mathrm{URs})$ and $40.5 \%$ non-urbans $(N=$ 83; 1582 URs).

This study shows that the practice of herbal medicines is relatively active in French Guiana, since $77.5 \%$ of the people interviewed (163/205 individuals) regularly use herbal remedies (at least once every 6 months). Thus, contrary to a preconceived idea of a certain disintegration of traditional medicines linked to urbanization and a modernization of lifestyles, phytotherapeutic practices and knowledge are still alive on the French Guianese coast, and this even in the city (17.2 citations on average among city dwellers, 2101/3683 URs, 122 individualsagainst 18.2 among rural dwellers, 1582/3683 URs, 87 individuals counted). Moreover, this persistent use of medicinal plants is particularly marked within certain socio-cultural groups such as St Lucians, Maroons and French Caribbean Creoles, and French Guianese Creoles, who all count more than 14 uses per informant in average (Table 1).

\section{Botany: what species are used?}

A total of 356 species (belonging to 106 distinct families) were cited during this survey, for their medicinal, magic, or cosmetic properties, of which 212 have been collected for herbarium vouchers. Among the species for which any specimen was collected, most are very common (such as Musa x paradisiaca) and/or too difficult to process (such as Cocos nucifera) or do not exist in a living form in French Guiana (such as Ferula assa-foetida). Beyond the relatively high number of medicinal plants and the large variety of botanical families revealed by this inventory, it appears that some of them are particularly mobilized; 12 families are mainly represented, each comprising more than 100 URs. These are the Lamiaceae (218/3683 URs, for 18 species), Arecaceae (168 URs, 9 species), Fabaceae (167 URs, 22 species), Verbenaceae (164 URs, 7 species), Euphorbiaceae (153 URs, 11 species), Poaceae (147 URs, 10 species), Malvaceae (143 URs, 12 species), Asteraceae (140 URs, 27 species), Rutaceae (135 URs, 7 species), Zingiberaceae (127 URs, 6 species), and Piperaceae (107 URs, 7 species).

Among all the mentioned plants, 155 species, belonging to 62 different botanical families, are cited at least 5 times (Table 2) among which 57 species were particularly cited with more than 20 URs each. Another significant result is that, out of the 20 main species used in French Guiana, 15 can be considered as pantropical: Allium sativum, Aloe vera, Annona muricata, Citrus aurantiifolia, Cocos nucifera, Cymbopogon citratus, Eryngium foetidum, Gossypium barbadense, Kalanchoe pinnata, Lippia alba, Ocimum basilicum, Momordica charantia, Peperomia pellucida, Ricinus communis, and Zingiber officinale.

In addition, edible species hold a special place in migrants' pharmacopeias (in our sample of respondents, these are Brazilian, Dominican, Haitian, Guyanese, Peruvian, and Surinamese informants) since they represent more than a third of the species used by migrants (34.0\%; 177/521 URs) and one fifth for the whole population (20.4\%; 751/3683).

Finally, it is to be noted that, if compared to previous inventories [38, 39], 31 "new" species can be counted including 22 living plants: Alpinia zerumbet, 34 URs; Artemisia absinthium, 4 URs; Blighia sapida, 1 UR; Cannabis sativa, 10 URs; Guazuma ulmifolia, 2 URs; Lippia micromera, 12 URs; Melaleuca quinquenervia, 3 URs; Morinda citrifolia, 24 URs; Moringa oleifera, 6 URs; Petroselinum crispum, 7 URs; Pimenta racemosa, 15 URs; Plectranthus grandis, 11 URs; Plectranthus neochilus, 13 
Table 2 List of the 151 main medicinal species ( $\geq 5$ usage citations) mentioned on the coastal area of French Guiana, ranked in descending order of citations in the surveys

\begin{tabular}{|c|c|c|c|c|c|c|}
\hline Species (herbarium no.) & Family & Citations & $\begin{array}{l}\text { Transversality (number of } \\
\text { cultural groups concerned) }\end{array}$ & Origin & Status & Habitat \\
\hline Cymbopogon citratus (DC.) Stapf (MAT 165) & Poaceae & 113 & 16 & AS & C & G \\
\hline Cocos nucifera L. & Arecaceae & 92 & 14 & AS & W/C & $\mathrm{G} / \mathrm{R}$ \\
\hline Citrus aurantiifolia (Christm.) Swingle (MAT 07) & Rutaceae & 85 & 15 & AS & $\mathrm{C}$ & G \\
\hline Gossypium barbadense L. (MAT 170) & Malvaceae & 77 & 11 & AM & C & G \\
\hline Quassia amara L. (MAT 452) & Simaroubaceae & 72 & 12 & AM & W/C & $\mathrm{G} / \mathrm{F}$ \\
\hline Aloe vera (L.) Burm.f. (MAT 93) & Xanthorrhoeaceae & 67 & 15 & AM & C & G \\
\hline Lippia alba (Mill.) N.E.Br. ex Britton \& P.Wilson & Verbenaceae & 67 & 11 & AM & C & G \\
\hline Ricinus communis $\mathrm{L}$. & Euphorbiaceae & 66 & 11 & AF & C & G \\
\hline Siparuna guianensis Aubl. (MAT 293) & Siparunaceae & 66 & 12 & AM & W & $\mathrm{G} / \mathrm{F}$ \\
\hline Carapa guianensis Aubl. & Meliaceae & 65 & 12 & AM & W & $F / I$ \\
\hline Momordica charantia L. (MAT 299) & Cucurbitaceae & 60 & 10 & $A F$ & $\mathrm{P} / \mathrm{C}$ & $R / G$ \\
\hline Astrocaryum vulgare Mart. & Arecaceae & 58 & 10 & AM & W & $\mathrm{R}$ \\
\hline Eryngium foetidum L. (MAT 497) & Apiaceae & 55 & 10 & AS & C & G \\
\hline Annona muricata L. (MAT 180) & Annonaceae & 52 & 12 & AM & C & G \\
\hline Allium sativum $\mathrm{L}$. & Amaryllidaceae & 52 & 12 & EU & C & I \\
\hline Peperomia pellucida (L.) Kunth (MAT 109) & Piperaceae & 49 & 10 & AM & $P$ & G \\
\hline Tinospora crispa (L.) Hook. f. \& Thomson (MAT 265) & Menispermaceae & 48 & 8 & AS & C & G \\
\hline Kalanchoe pinnata (Lam.) Pers. (MAT 135) & Crassulaceae & 45 & 13 & AF & C & G \\
\hline Zingiber officinale Roscoe & Zingiberaceae & 45 & 11 & AS & C & G \\
\hline $\begin{array}{l}\text { Ocimum basilicum } \mathrm{L} \text {. } \\
\text { Ocimum campechianum Mill. (MAT 150) } \\
\text { Ocimum minimum } \mathrm{L} \text {. }\end{array}$ & Lamiaceae & 43 & 8 & $\begin{array}{l}\text { AS/ } \\
\text { AM }\end{array}$ & $C / P$ & $\mathrm{G} / \mathrm{R}$ \\
\hline Phyllanthus amarus Schumach. \& Thonn. (MAT 303) & Phyllanthaceae & 43 & 10 & AF & $P$ & $R / G$ \\
\hline Chenopodium ambrosioides L. (MAT 448) & Amaranthaceae & 42 & 7 & AM & C & G \\
\hline Lantana camara L. (MAT 298) & Verbenaceae & 41 & 10 & AM & C & G \\
\hline Citrus $\times$ aurantium L. (MAT 498) & Rutaceae & 40 & 9 & AS & C & G \\
\hline Cinnamomum verum J. Presl & Lauraceae & 39 & 9 & AS & C & G \\
\hline Petiveria alliacea L. (MAT 173) & Phytolaccaceae & 39 & 7 & AM & C & G \\
\hline Piper marginatum Jacq. (MAT 263) & Piperaceae & 36 & 9 & AM & W & R \\
\hline $\begin{array}{l}\text { Senna alata (L.) Roxb. (MAT 325) } \\
\text { Senna reticulata (Willd.) H.S.Irwin \& Barneby }\end{array}$ & Fabaceae & 36 & 11 & AM & W/C & $\mathrm{R}$ \\
\hline Annona squamosa L. (MAT 181) & Annonaceae & 35 & 5 & AM & C & G \\
\hline Curcuma longa L. (MAT 221) & Zingiberaceae & 35 & 10 & AS & C & G \\
\hline Costus spiralis (Jacq.) Roscoe (MAT 205) & Costaceae & 35 & 8 & AM & W/C & $R / G$ \\
\hline Aristolochia trilobata L. (MAT 128) & Aristolochiaceae & 34 & 4 & AM & C & G \\
\hline Alpinia zerumbet (Pers.) B.L. Burtt \& R.M. Sm. (MAT 163) & Zingiberaceae & 34 & 6 & AS & C & G \\
\hline Ayapana triplinervis (Vahl) R.M. King \& H. Rob. (MAT 234) & Asteraceae & 34 & 8 & AM & C & G \\
\hline Anacardium occidentale L. (MAT 194) & Anacardiaceae & 33 & 14 & AM & W/C & $\mathrm{G} / \mathrm{R}$ \\
\hline Manihot esculenta Crantz & Euphorbiaceae & 33 & 6 & AM & C & G \\
\hline Leonotis nepetifolia (L.) R.Br. & Lamiaceae & 29 & 9 & AM & C & G \\
\hline Psidium guajava L. (MAT 499) & Myrtaceae & 29 & 12 & AM & $\mathrm{C}$ & G \\
\hline Tetradenia riparia (Hochst.) Codd (MAT 199) & Lamiaceae & 28 & 8 & AS & C & G \\
\hline Stachytarpheta jamaicensis (L.) Vahl (MAT 174) & Verbenaceae & 28 & 7 & AM & W/C & $\mathrm{G} / \mathrm{R}$ \\
\hline
\end{tabular}


Table 2 List of the 151 main medicinal species ( $\geq 5$ usage citations) mentioned on the coastal area of French Guiana, ranked in descending order of citations in the surveys (Continued)

\begin{tabular}{|c|c|c|c|c|c|c|}
\hline Species (herbarium no.) & Family & Citations & $\begin{array}{l}\text { Transversality (number of } \\
\text { cultural groups concerned) }\end{array}$ & Origin & Status & Habitat \\
\hline Scoparia dulcis L. (MAT 295) & Plantaginaceae & 27 & 9 & AM & $P$ & $R / R$ \\
\hline Carica papaya L. & Caricaceae & 26 & 10 & AM & C & G \\
\hline Hibiscus rosa-sinensis L. (MAT 501) & Malvaceae & 26 & 9 & AS & C & G \\
\hline Senna alexandrina Mill. & Fabaceae & 26 & 6 & AF & C & 1 \\
\hline Cecropia spp. & Urticaceae & 25 & 8 & AM & W & $\mathrm{R}$ \\
\hline Eleutherine bulbosa (Mill.) Urb. (MAT 223) & Iridaceae & 25 & 6 & AM & C & G \\
\hline Morinda citrifolia L. (MAT 124) & Rubiaceae & 24 & 8 & AS & C & G \\
\hline Mangifera indica L. (MAT 510) & Anacardiaceae & 24 & 10 & AM & C & G \\
\hline Solanum leucocarpon Dunal (MAT 331) & Solanaceae & 24 & 6 & AM & C & G \\
\hline Justicia pectoralis Jacq. (MAT 500) & Acanthaceae & 22 & 5 & AM & C & G \\
\hline Musa $\times$ paradisiaca. & Musaceae & 22 & 7 & AS & C & G \\
\hline Portulaca oleracea L. (MAT 107) & Portulacaceae & 22 & 7 & $\mathrm{CO}$ & C & G \\
\hline Plectranthus amboinicus (Lour.) Spreng. (MAT 162) & Lamiaceae & 21 & 8 & AS & C & G \\
\hline Mansoa alliacea (Lam.) A.H.Gentry (MAT 285) & Bignoniaceae & 19 & 8 & AM & W/C & $\mathrm{G} / \mathrm{F}$ \\
\hline Senna occidentalis (L.) Link (MAT 104) & Fabaceae & 19 & 5 & AM & C & G \\
\hline Chromolaena odorata (L.) R.M. King \& H.Rob. (MAT 228) & Asteraceae & 18 & 8 & AM & W & $\mathrm{R}$ \\
\hline Capraria biflora L. (MAT 492) & Scrophulariaceae & 17 & 5 & AM & $\mathrm{C}$ & G \\
\hline Geissospermum spp. & Apocynaceae & 17 & 6 & AM & W & $\mathrm{F}$ \\
\hline Crescentia cujete L. (MAT 502) & Bignoniaceae & 16 & 7 & AM & C & G \\
\hline Copaifera spp. & Fabaceae & 16 & 6 & AM & W & $F / l$ \\
\hline Jatropha curcas L. (MAT 192) & Euphorbiaceae & 16 & 6 & AM & C & G \\
\hline Jatropha gossypiifolia L. (MAT 164) & Euphorbiaceae & 15 & 7 & AM & C & G \\
\hline Myristica fragrans Houtt. & Myristicaceae & 15 & 6 & AS & C & $\mathrm{G} / \mathrm{l}$ \\
\hline Orthosiphon aristatus (Blume) Miq. (MAT 509) & Lamiaceae & 15 & 5 & AS & C & G \\
\hline Ocotea guianensis Aubl. (MAT 453) & Lauraceae & 15 & 5 & AM & W & $\mathrm{R}$ \\
\hline Priva lappulacea (L.) Pers. (MAT 503) & Verbenaceae & 15 & 6 & AM & W & $\mathrm{R}$ \\
\hline Pimenta racemosa (Mill.) J.W.Moore (MAT 175) & Myrtaceae & 15 & 4 & AM & C & $\mathrm{G} / \mathrm{l}$ \\
\hline Sambucus simpsonii Rehder (MAT 225) & Adoxaceae & 15 & 3 & AM & C & G \\
\hline Opuntia cochenillifera (L.) Mill. (MAT 491) & Cactaceae & 14 & 6 & AM & C & G \\
\hline Fraxinus ornus L. & Oleaceae & 13 & 2 & EU & W & । \\
\hline Plectranthus neochilus Schltr. (MAT 157) & Lamiaceae & 13 & 7 & AS & C & G \\
\hline Piper peltatum L. (MAT 169) & Piperaceae & 13 & 6 & AM & W & $\mathrm{R}$ \\
\hline Allium cepa $\mathrm{L}$. & Amaryllidaceae & 12 & 6 & AS & C & $\mathrm{G} / \mathrm{l}$ \\
\hline Dalbergia monetaria L.f. (MAT 281) & Fabaceae & 12 & 7 & AM & W & $\mathrm{R}$ \\
\hline Hyptis atrorubens Poit. (MAT 138) & Lamiaceae & 12 & 4 & AM & W & $\mathrm{R}$ \\
\hline Lippia micromera Schauer (MAT 490) & Verbenaceae & 12 & 9 & AM & C & G \\
\hline Mimosa pudica L. (MAT 266) & Fabaceae & 12 & 5 & AM & W & $\mathrm{R}$ \\
\hline Macfadyena unguis-cati (L.) A.H. Gentry (MAT 233) & Bignoniaceae & 12 & 4 & AM & W & $\mathrm{F}$ \\
\hline Mentha spp. & Lamiaceae & 12 & 9 & AS & C & G \\
\hline Nicotiana tabacum L. & Solanaceae & 12 & 8 & AM & C & G \\
\hline Persea americana Mill. & Lauraceae & 12 & 4 & AM & C & G \\
\hline Arrabidaea chica (Humb. \& Bonpl.) Verl. (MAT 166) & Bignoniaceae & 11 & 5 & AM & W/C & $\mathrm{G} / \mathrm{F}$ \\
\hline Euterpe oleracea Mart. & Arecaceae & 11 & 6 & AM & W & $\mathrm{F}$ \\
\hline
\end{tabular}


Table 2 List of the 151 main medicinal species ( $\geq 5$ usage citations) mentioned on the coastal area of French Guiana, ranked in descending order of citations in the surveys (Continued)

\begin{tabular}{|c|c|c|c|c|c|c|}
\hline Species (herbarium no.) & Family & Citations & $\begin{array}{l}\text { Transversality (number of } \\
\text { cultural groups concerned) }\end{array}$ & Origin & Status & Habita \\
\hline $\begin{array}{l}\text { Plectranthus barbatus var. grandis (L.H.Cramer) Lukhoba \& } \\
\text { A.J.Paton }\end{array}$ & Lamiaceae & 11 & 6 & AS & C & G \\
\hline Pfaffia glomerata (Spreng.) Pedersen (MAT 493) & Amaranthaceae & 11 & 3 & AM & C & G \\
\hline Sida glomerata Cav. (MAT 155) & Malvaceae & 11 & 3 & AM & W & $\mathrm{R}$ \\
\hline Spondias mombin L. & Anacardiaceae & 11 & 6 & AM & W/D & $\mathrm{F} / \mathrm{G}$ \\
\hline Saccharum officinarum L. & Poaceae & 11 & 6 & AS & C & G \\
\hline Averrhoa bilimbi L. & Oxalidaceae & 10 & 5 & AS & C & G \\
\hline Cinnamomum camphora (L.) J.Presl & Lauraceae & 10 & 4 & AS & C & । \\
\hline Cassia fistula L. (MAT 489) & Fabaceae & 10 & 3 & AS & C & G \\
\hline Cannabis sativa L. (MAT 125) & Cannabaceae & 10 & 5 & AS & C & $\mathrm{G} / \mathrm{l}$ \\
\hline Euphorbia thymifolia L. (MAT 243) & Euphorbiaceae & 10 & 5 & AM & W & $\mathrm{R}$ \\
\hline Marsypianthes chamaedrys (Vahl) Kuntze (MAT 140) & Lamiaceae & 10 & 3 & AM & W & $\mathrm{R}$ \\
\hline Pogostemon heyneanus Benth. (MAT 152) & Lamiaceae & 10 & 3 & AS & C & G \\
\hline Syzygium aromaticum (L.) Merr. \& L.M. Perry & Myrtaceae & 10 & 5 & AS & C & G \\
\hline Mikania congesta DC. (MAT 186) & Asteraceae & 9 & 5 & AM & W & $\mathrm{R}$ \\
\hline Spondias dulcis Parkinson & Anacardiaceae & 9 & 4 & AM & C & G \\
\hline Tabebuia serratifolia (Vahl) G. Nicholson (MAT 317) & Bignoniaceae & 9 & 6 & AM & W & $\mathrm{F}$ \\
\hline Abelmoschus esculentus (L.) Moench & Malvaceae & 8 & 3 & AF & C & G \\
\hline Bixa orellana $\mathrm{L}$. & Bixaceae & 8 & 4 & AM & C & G \\
\hline Vernonia condensata Baker (MAT 188) & Asteraceae & 8 & 5 & AM & W & $\mathrm{F}$ \\
\hline Capsicum annuum L. & Solanaceae & 8 & 7 & AM & C & G \\
\hline Cordyline fruticosa (L.) A.Chev. (MAT 179) & Asparagaceae & 8 & 4 & AS & C & G \\
\hline Eugenia uniflora L. (MAT 488) & Myrtaceae & 8 & 2 & AM & C & G \\
\hline Hymenaea courbaril L. & Fabaceae & 8 & 4 & AM & W & $\mathrm{F}$ \\
\hline Protium heptaphyllum (Aubl.) Marchand (MAT 229) & Burseraceae & 8 & 4 & AM & W & $\mathrm{F}$ \\
\hline Pilea microphylla L. (MAT 494) & Urticaceae & 8 & 2 & AM & W & G \\
\hline Terminalia catappa L. (MAT 504) & Combretaceae & 8 & 5 & AS & W/C & $G / R$ \\
\hline Artocarpus altilis (Parkinson ex F.A.Zorn) Fosberg & Moraceae & 7 & 4 & AS & C & G \\
\hline Alternanthera brasiliana (L.) Kuntze (MAT 289) & Amaranthaceae & 7 & 3 & AM & C & G \\
\hline Elephantopus mollis Kunth (MAT 132) & Asteraceae & 7 & 4 & AM & W & $\mathrm{R}$ \\
\hline Justicia secunda Vahl (MAT 487) & Acanthaceae & 7 & 3 & AM & C & G \\
\hline Laportea aestuans (L.) Chew (MAT 154) & Urticaceae & 7 & 3 & AM & W & $R / G$ \\
\hline Neurolaena lobata (L.) Cass. & Asteraceae & 7 & 3 & AM & C & । \\
\hline Petroselinum crispum (Mill.) Fuss & Apiaceae & 7 & 4 & EU & C & G \\
\hline Passiflora edulis Sims & Passifloraceae & 7 & 6 & AM & C & G \\
\hline Cyperus odoratus L. (MAT 248) & Cyperaceae & 7 & 3 & AM & C & $G / R$ \\
\hline Sphagneticola trilobata (L.) Pruski (MAT 226) & Asteraceae & 7 & 3 & AM & C & $\mathrm{G} / \mathrm{R}$ \\
\hline Begonia glabra Aubl. (MAT 297) & Begoniaceae & 6 & 3 & AM & W/D & $\mathrm{F} / \mathrm{G}$ \\
\hline Campomanesia aromatica (Aubl.) Griseb. & Myrtaceae & 6 & 3 & AM & W & $\mathrm{R}$ \\
\hline Clidemia hirta (L.) D. Don (MAT 159) & Melastomataceae & 6 & 4 & AM & W & $\mathrm{R}$ \\
\hline Caesalpinia pulcherrima (L.) Sw. (MAT 508) & Fabaceae & 6 & 2 & $\mathrm{AF}$ & C & G \\
\hline Catharanthus roseus (L.) G. Don & Apocynaceae & 6 & 3 & AF & C & G \\
\hline Coutoubea spicata Aubl. (MAT 127) & Gentianaceae & 6 & 3 & AM & W & $\mathrm{R}$ \\
\hline
\end{tabular}


Table 2 List of the 151 main medicinal species ( $\geq 5$ usage citations) mentioned on the coastal area of French Guiana, ranked in descending order of citations in the surveys (Continued)

\begin{tabular}{|c|c|c|c|c|c|c|}
\hline Species (herbarium no.) & Family & Citations & $\begin{array}{l}\text { Transversality (number of } \\
\text { cultural groups concerned) }\end{array}$ & Origin & Status & Habitat \\
\hline Cucurbita maxima Duchesne & Cucurbitaceae & 6 & 2 & AM & C & G \\
\hline Dipteryx odorata (Aubl.) Willd. & Fabaceae & 6 & 2 & AM & W & $\mathrm{F}$ \\
\hline Euphorbia hirta L. (MAT 495) & Euphorbiaceae & 6 & 3 & AS & W & $\mathrm{F} / \mathrm{I}$ \\
\hline Ferula assa-foetida L. & Apiaceae & 6 & 3 & AF & C & । \\
\hline Inga spp. & Fabaceae & 6 & 2 & AM & C & G \\
\hline Moringa oleifera Lam. (MAT 507) & Moringaceae & 6 & 5 & AS & C & G \\
\hline Polyscias scutellaria (Burm.f.) Fosberg (MAT 505) & Araliaceae & 6 & 3 & AM & C & G \\
\hline Renealmia sp. & Zingiberaceae & 6 & 3 & AM & W/D & $F / G$ \\
\hline Syzygium malaccense (L.) Merr. \& L.M. Perry (MAT 137) & Myrtaceae & 6 & 3 & AS & C & G \\
\hline Theobroma cacao L. & Malvaceae & 6 & 3 & AM & C & G \\
\hline Zea mays $L$. & Poaceae & 6 & 3 & AM & C & G \\
\hline Ageratum conyzoides L. (MAT 231) & Asteraceae & 5 & 2 & AM & W & $\mathrm{R}$ \\
\hline Aframomum melegueta K. Schum. (MAT 334) & Zingiberaceae & 5 & 2 & AF & C & । \\
\hline Artemisia spp. & Asteraceae & 5 & 3 & EU & C & G \\
\hline Bidens cynapiifolia Kunth (MAT 275) & Asteraceae & 5 & 3 & AM & W & $\mathrm{R}$ \\
\hline Cajanus cajan (L.) Millsp. (MAT 486) & Fabaceae & 5 & 2 & AF & C & G \\
\hline Cordia curassavica (Jacq.) Roem. \& Schult. (MAT 300) & Boraginaceae & 5 & 3 & AM & W & $\mathrm{R}$ \\
\hline Commelina erecta L. (MAT 310) & Commelinaceae & 5 & 4 & AM & C & G \\
\hline Coffea spp. & Rubiaceae & 5 & 3 & AF & C & 1 \\
\hline Tanaecium bilabiatum (Sprague) L.G. Lohmann & Bignoniacée & 5 & 2 & AM & W & $\mathrm{F}$ \\
\hline Malpighia emarginata DC (MAT 496). & Malpighiaceae & 5 & 4 & AM & C & G \\
\hline Plantago major L. (MAT 506) & Plantaginaceae & 5 & 2 & EU & C & G \\
\hline Picrolemma sprucei Hook. f. & Simaroubaceae & 5 & 4 & AM & C & $\mathrm{F}$ \\
\hline Rolandra fruticosa (L.) Kuntze (MAT 203) & Asteraceae & 5 & 3 & AM & W & $\mathrm{R}$ \\
\hline Struchium sparganophorum (L.) Kuntze (MAT 101) & Asteraceae & 5 & 2 & AS & C & G \\
\hline Averrhoa carambola L. & Oxalidaceae & 5 & 1 & AS & C & G \\
\hline
\end{tabular}

"Origin": AS Asia, AM America, AF Africa, EU Europe, CO cosmopolitan. "Status": C cultivated, $W$ wild, $P$ protected, $D$ domesticated. "Habitat": $G$ garden, $F$ forest, $R$ ruderal, I imported

URs; Polyscias scutellaria, 6 URs; Porophyllum ruderale, 2 URs; Punica granatum, 2 URs; Scutellaria purpurascens, 2 URs; Tanaecium bilabiatum, 5 URs; Tetradenia riparia, 28 URs; Theobroma grandiflorum, 1 UR; Vernonia condensata, 8 URs; and Syzygium malaccense, 6 URs.

\section{Cross-culturalism: a widely shared medicinal flora}

This study highlights the diversity of medicinal plants in use on the French Guianese coast and shows that the majority of the plants used are not specific to a particular group but shared by many communities. More than $3 / 4$ of the species are cited by at least 5 of the cultural groups questioned during the survey, and $31.3 \%$ of them are used in more than 10 among the 15 groups questioned (Fig. 2). Only one species appears to be exclusive to a single community (Averrhoa carambola, cited only by French Guianese Creoles), but due to the low number of URs (only 4), it does not appear as an indicator. Community groups and individuals do not automatically consider each plant for the same use but it means at least that therapeutic properties are recognized for this plant within different communities. This does not mean that these groups use them for the same uses, but that they know these plants and their therapeutic properties.

Some cross-cultural species (Aloe vera, Citrus aurantiifolia, Cymbopogon citratus, Ricinus communis, Zingiber officinale...) are considered as true panaceas whose miscellaneous purposes uses are widely disseminated in the whole population, making them constitutive of a widely shared medicinal flora. 


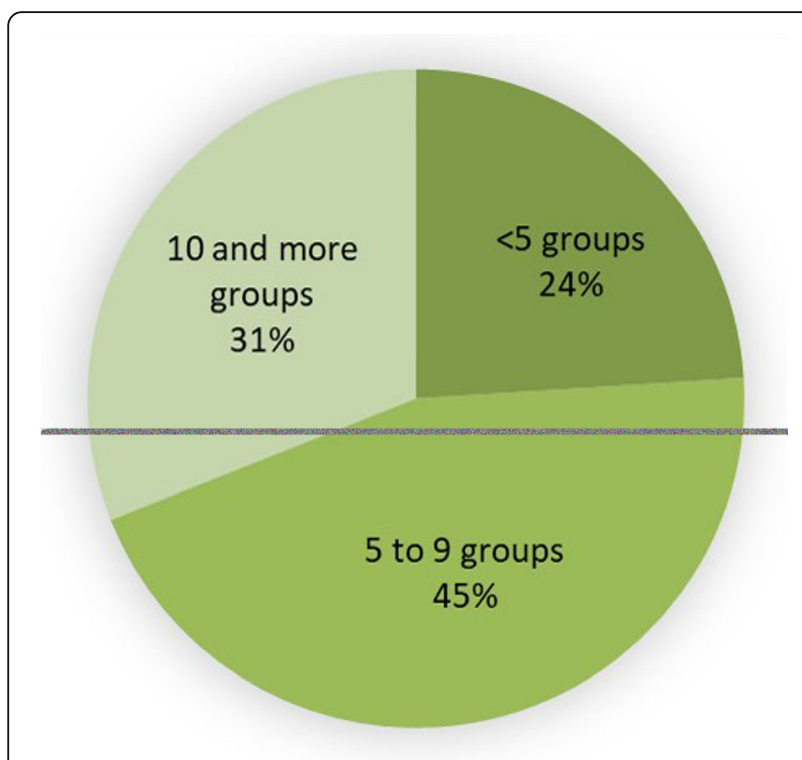

Fig. 2 Distribution of species (in percentage of species) according to the number of cultural groups using them

\section{Divergences and specificities: "Show me which plants you} use, I will tell you who you are"

However, despite these shared uses of medicinal plants among the different cultural communities of French Guiana, divergent trends nevertheless appear. The importance of cultural keystone species [40] to defining cultural identities is acknowledged in ethnobotany, but detecting them in a multicultural context might be difficult. To do so, a statistical analysis borrowed from community ecology was performed as described in the "Methods" section.

This analysis led to the identification of 29 indicator/ cultural keystone species in 10 cultural groups from the 12 considered ( $c f$. "Methods" section), as no species were highlighted for two of them: kra and plk (Table 3). In the table, the higher the value of the Indval index is and the lower the $p$ value is, the more closely related the indicator species is with the cultural group associated.

A redundancy analysis (RDA) model was built with cultural groups as predictive factors and (a) the whole species dataset suitable for analysis and (b) the set of 205 observations of indicator species. In both cases, the difference of the RDA model built with cultural as predictive with a null model (H0: the species distribution in pharmacopeias of the different persons interviewed is due to randomness) is significant. The percentage of the variation observed in species distribution explained by socio-cultural origin varies from $7.4 \%$ (a) to $16.6 \%$ (b) when considering only indicator species. While this rate reveals that cultural groups influence pharmacopeias species composition, the fact remains that other variables (age, sex, place of life, etc.) might also play important roles.

The triplot below (Fig. 3) is a representation of the constrained RDA model allowing to visualize the relative position of indicator species among the different groups in a virtual space.

We observe first of all that the group including the Amerindians Karipuna and Galibi-Marwono (galkar) is the one that is affected by the largest number of indicator species (8 species out of 29). In fact, these are species widely used in Brazil [41] and by the inhabitants of eastern French Guiana, border with Brazil (in particular, Carapa guianensis, Dalbergia monetaria, Mansoa alliacea, Picrolemma sprucei, Vernonia condensata), where the majority of the individuals of the two aforementioned groups live. However, statistical analysis may have given them disproportionate weight given the numerical differences between the groups interviewed.

All the results are consistent with the qualitative observations made in the field in terms of culturally marked practices. Some keystone species, much valued by certain cultural communities, do not necessarily appear as indicators and some are more transverse than it seems from the discourses. This is the case, for example, of Quassia amara whose attempts at cultural appropriation by certain communities which does not emerge as an indicator species of any particular cultural group from French Guiana, meaning that nowadays it is used by several groups, precisely 8 out of the 12 groups considered. Moreover, some species indicative of local groups are coming from distant regions, like Fraxinus ornus of which the exudate is used by the French Guianese Créoles as an ingredient in purgative cures, or Catharanthus roseus, native to the Indian Ocean, which stands out as being the only indicator species for the group of Kali'na Amerindians. Finally, Latin American migrants preferentially use cultivated pantropical food species (Allium cepa, Passiflora edulis, Plectranthus amboinicus), while local (and wild) species are more widely used by long-established cultural groups (Amerindians and Maroons), who are often farmers and therefore have a daily connection with the surrounding flora.

\section{Access strategies and transmission}

The analysis of the responses to the semi-structured interviews carried out made it possible to measure the proportion of the different modes of access to medicinal plants on the French Guiana coast. We observe that $39.3 \%$ of the plants used are cultivated by the users themselves (1448/3683) and 31.6\% come from picking, either in forested or urban areas (1163/3683 URs), and $20.4 \%$ are purchased commercially (752/3683). The networks of exchanges between relatives (family and acquaintances: friends, neighbors, and colleagues) total 
Table 3 List of the 29 indicator species associated with 10 cultural groups from French Guiana and classified according to the decreasing Indval index

\begin{tabular}{|c|c|c|c|c|}
\hline $\begin{array}{l}\text { Species } \\
\text { Family }\end{array}$ & Indval & URs & $\boldsymbol{P}$ value & Associated groups \\
\hline $\begin{array}{l}\text { Allium cepa } \mathrm{L} \text {. } \\
\text { Amaryllidaceae }\end{array}$ & 0.430 & 11 & $0.002^{* *}$ & Peruvians and Dominicans \\
\hline $\begin{array}{l}\text { Vernonia condensata Baker } \\
\text { Asteraceae }\end{array}$ & 0.393 & 8 & $0.003^{* *}$ & Galibi-Marwono et Karipuna \\
\hline $\begin{array}{l}\text { Carapa guianensis Aubl. } \\
\text { Meliaceae }\end{array}$ & 0.354 & 57 & $0.001^{* * *}$ & Galibi-Marwono et Karipuna \\
\hline $\begin{array}{l}\text { Persea americana Mill. } \\
\text { Lauraceae }\end{array}$ & 0.349 & 11 & $0.001^{* * *}$ & Guyanese \\
\hline $\begin{array}{l}\text { Momordica charantia L. } \\
\text { Cucurbitaceae }\end{array}$ & 0.337 & 51 & $0.001^{* * *}$ & Haitians \\
\hline $\begin{array}{l}\text { Lippia micromera Schauer } \\
\text { verbenaceae }\end{array}$ & 0.311 & 11 & $0.004^{* *}$ & Europeans \\
\hline $\begin{array}{l}\text { Picrolemma sprucei Hook. f. } \\
\text { Simaroubaceae }\end{array}$ & 0.310 & 4 & $0.011^{*}$ & Galibi-Marwono et Karipuna \\
\hline $\begin{array}{l}\text { Wedelia trilobata (L.) Hitchc. } \\
\text { Asteraceae }\end{array}$ & 0.306 & 5 & $0.011^{*}$ & Guyanese \\
\hline $\begin{array}{l}\text { Petiveria alliacea } \mathrm{L} \text {. } \\
\text { Phytolaccaceae }\end{array}$ & 0.302 & 31 & $0.003^{* *}$ & Galibi-Marwono et Karipuna \\
\hline $\begin{array}{l}\text { Astrocaryum vulgare Mart. } \\
\text { Areceaceae }\end{array}$ & 0.292 & 42 & $0.002^{* *}$ & Galibi-Marwono et Karipuna \\
\hline $\begin{array}{l}\text { Abelmoschus esculentus (L.) Moench } \\
\text { Malvaceae }\end{array}$ & 0.291 & 8 & $0.006^{* *}$ & Guyanese \\
\hline $\begin{array}{l}\text { Mansoa alliacea (Lam.) A.H. Gentry } \\
\text { Bignoniaceae }\end{array}$ & 0.290 & 14 & $0.005^{* *}$ & Galibi-Marwono et Karipuna \\
\hline $\begin{array}{l}\text { Cecropia spp. } \\
\text { Urticaceae }\end{array}$ & 0.255 & 20 & $0.011^{*}$ & Guyanese \\
\hline $\begin{array}{l}\text { Jatropha gossypifolia L. } \\
\text { Euphorbiaceae }\end{array}$ & 0.237 & 12 & $0.011^{*}$ & Galibi-Marwono et Karipuna \\
\hline $\begin{array}{l}\text { Catharanthus roseus (L.) G. Don } \\
\text { Apocynaceae }\end{array}$ & 0.212 & 6 & $0.038^{*}$ & Kali'na \\
\hline $\begin{array}{l}\text { Fraxinus ornus L. } \\
\text { Oleaceae }\end{array}$ & 0.197 & 12 & $0.034^{*}$ & French Guianese Créoles \\
\hline $\begin{array}{l}\text { Passiflora edulis Sims } \\
\text { Passifloraceae }\end{array}$ & 0.196 & 4 & $0.009^{* *}$ & Peruvians and Dominicans \\
\hline $\begin{array}{l}\text { Dalbergia monetaria L. f. } \\
\text { Fabaceae }\end{array}$ & 0.188 & 11 & $0.039^{*}$ & Galibi-Marwono et Karipuna \\
\hline $\begin{array}{l}\text { Piper peltatum L. } \\
\text { Piperaceae }\end{array}$ & 0.183 & 11 & $0.049^{*}$ & St Lucians \\
\hline $\begin{array}{l}\text { Annona squamosa } \mathrm{L} \text {. } \\
\text { Bromeliaceae }\end{array}$ & 0.182 & 29 & $0.047^{*}$ & St Lucians \\
\hline $\begin{array}{l}\text { Chenopodium ambrosioides } \mathrm{L} \text {. } \\
\text { Amaranthaceae }\end{array}$ & 0.179 & 38 & $0.024^{*}$ & Brazilians \\
\hline $\begin{array}{l}\text { Phyllanthus amarus Schumach. \& Thonn. } \\
\text { Phyllanthaceae }\end{array}$ & 0.179 & 40 & $0.029^{*}$ & St Lucians \\
\hline $\begin{array}{l}\text { Tanaecium bilabiatum (Sprague) L.G. Lohmann } \\
\text { Bignoniaceae }\end{array}$ & 0.167 & 5 & $0.030^{*}$ & Aluku, Paamaka, Ndjuka, Saamaka Maroons \\
\hline $\begin{array}{l}\text { Struchium sparganophorum (L.) Kuntze } \\
\text { Asteraceae }\end{array}$ & 0.167 & 5 & $0.031^{*}$ & Aluku, Paamaka, Ndjuka, Saamaka Maroons \\
\hline $\begin{array}{l}\text { Plectranthus amboinicus (Lour.) Spreng. } \\
\text { Lamiaceae }\end{array}$ & 0.159 & 18 & $0.042^{*}$ & Peruvians and Dominicans \\
\hline $\begin{array}{l}\text { Plantago major L. } \\
\text { Plantaginaceae }\end{array}$ & 0.143 & 5 & $0.033^{*}$ & St Lucians \\
\hline $\begin{array}{l}\text { Caesalpinia pulcherrima (L.) Sw. } \\
\text { Fabaceae }\end{array}$ & 0.143 & 5 & $0.039^{*}$ & St Lucians \\
\hline
\end{tabular}

*significant ( $p$ value comprised between 0.05 and 0.01 )

**highly significant ( $p$ value comprised between 0.01 and 0.001 )

***very highly significant ( $p$ value under 0.001 included) 


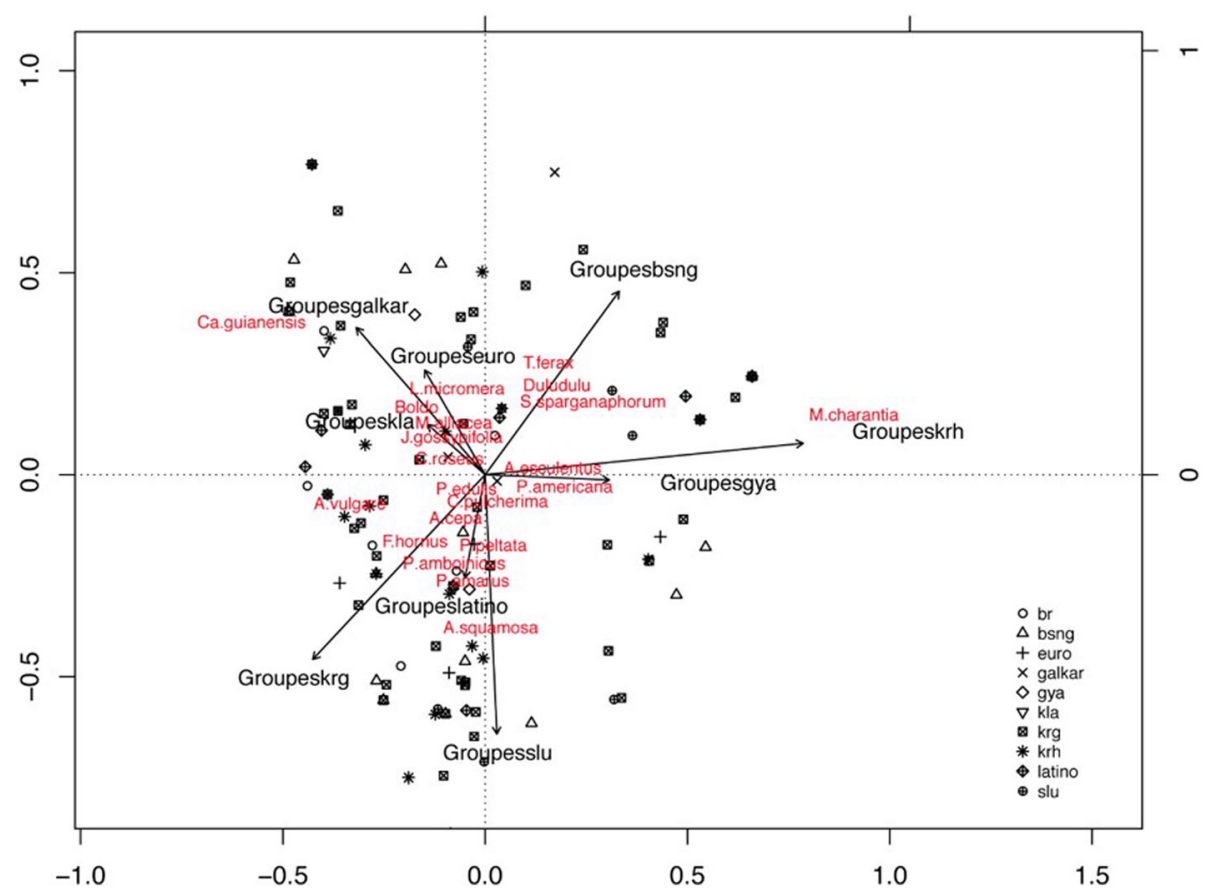

Fig. 3 Graphical representation of the RDA model allowing to visualize the association between 29 indicator species obtained and 10 cultural groups from French Guiana. "br" = Brazilians; "bsng" = Maroons; "euro" = Europeans; "galkar" = Galibi and Karipuna; "gya" = Guyanese; "kla" = Kali'na; "krg" = French Guianese Creoles; "krh" = Haitians; "latino" = Dominicans and Peruvians; "slu = St Lucians

$6.0 \%$ of citations (222 citations, of which 140 plants were given by a relative and 82 by an extra-familial acquaintance). In addition, another equally significant result is that 98 URs (2.7\% of total citations) come directly from outside French Guiana. These plants are generally brought by individuals (38 from Brazil, 26 from Suriname, 12 from Martinique, 9 from Haiti, 6 from St Lucia, 4 from Dominican Republic, 3 from Guadeloupe) who also bring with them processed products, like castor oil from the West Indies or Carapa guianensis oil from Brazil.

Then, in order to underline the diversity of intercultural exchanges, community profiles were drawn up for several groups, according to their level of permeability to exogenous knowledge and their ability to disseminate their own knowledge to other cultural groups. We first observe that this exchange web reveals inequalities both in terms of transmission and reception of knowledge (Fig. 4). Thus, the French Guianese Creoles and the Europeans seem to be relatively more assimilators of exotic knowledge while the Maroons, the St Lucians, and the Haitians transmit to other groups more than they receive from other communities.

More finely, when crossing the cultural affiliation of the respondents and the cultural affiliation of the people who transmitted to them the uses mentioned, it appears that the information is transmitted in more than $70 \%$ of the cases within the same cultural group, underlying that intercultural exchanges are a minority. However, this does not mean that intercultural exchanges are negligible since $14.8 \%$ of the uses of the plants mentioned were still transmitted horizontally (546/3683). Over a long period of time, it certainly influences the global patterns of knowledge. We also observe that the transmission of knowledge related to medicinal plants along the French Guiana coast remains essentially intracommunity and intergenerational, corresponding mainly to a vertical type transmission (Fig. 5).

In fact, $74.5 \%$ of the uses listed (2743/3683) were transmitted vertically, either exclusively female (mother, grandmother, aunt: 43.7\%, 1608/3683 URs), only male (father, grandfather, uncles: $10.3 \%, 379 / 3683$ URs), or mixed (parents, grandparents: 14.7\%, 546/3683 URs). Taking more widely into account every kind of transmission, women still hold a central place in the transmission of knowledge around medicinal plants in French Guiana since knowledge originating directly from women accounts for $54.1 \%$ of all transmissions (1993/3683), compared with $17.2 \%$ for those transmitted by men (632/3683 URs) and $28.6 \%$ from a mixed or undetermined gendered source (1053/3683 URs). In addition, if women transmit more than men, they also seem to be greater holders of knowledge since they total an average of 19.8 citations of plants (2355 URs for 119 women interviewed) against 15.4 for men (1328 URs for 86 men encountered). 


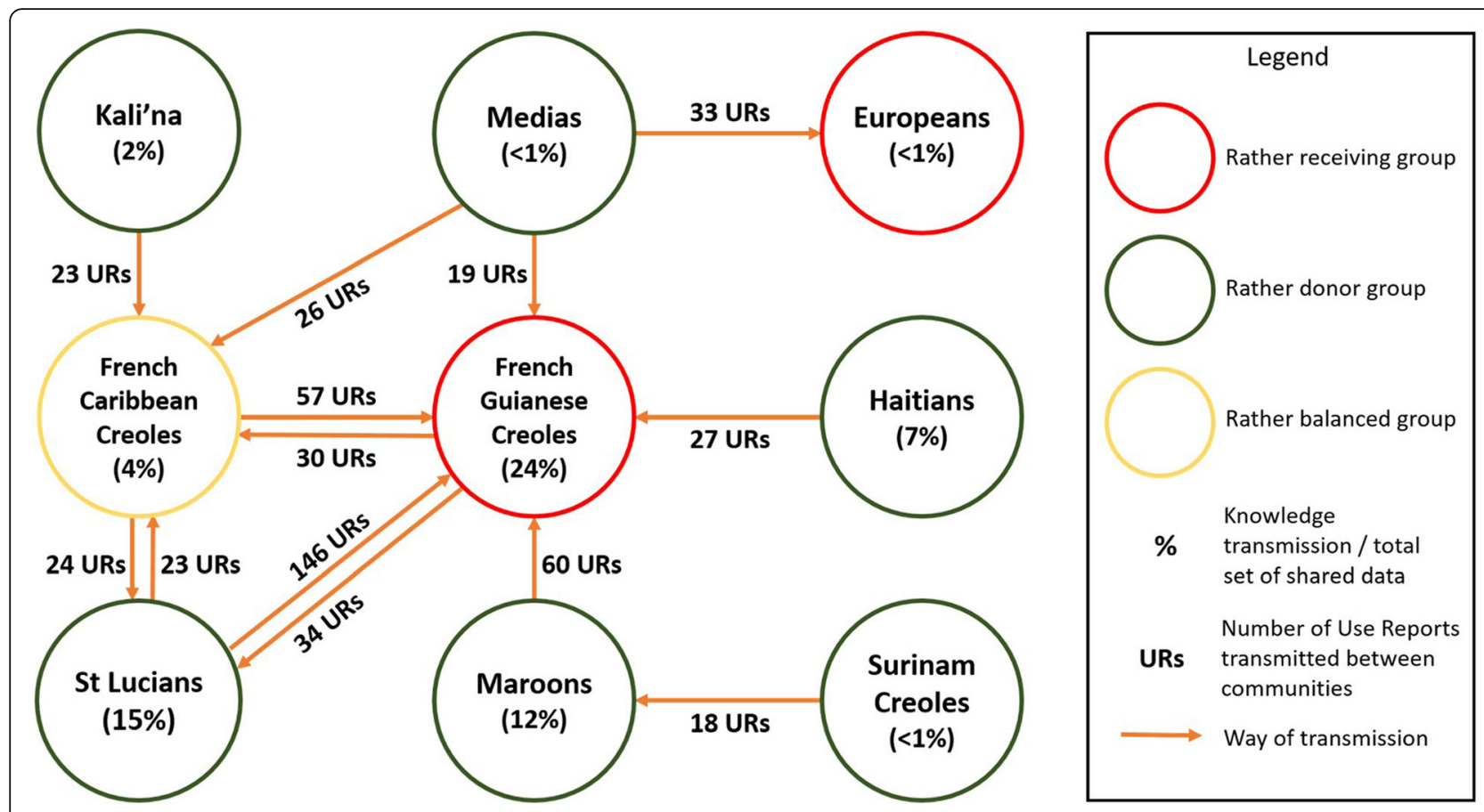

Fig. 4 Fluxes of phyto-medicinal knowledge on the Guiana coast. Permeability/porosity and capacity for dissemination by the different communities interviewed

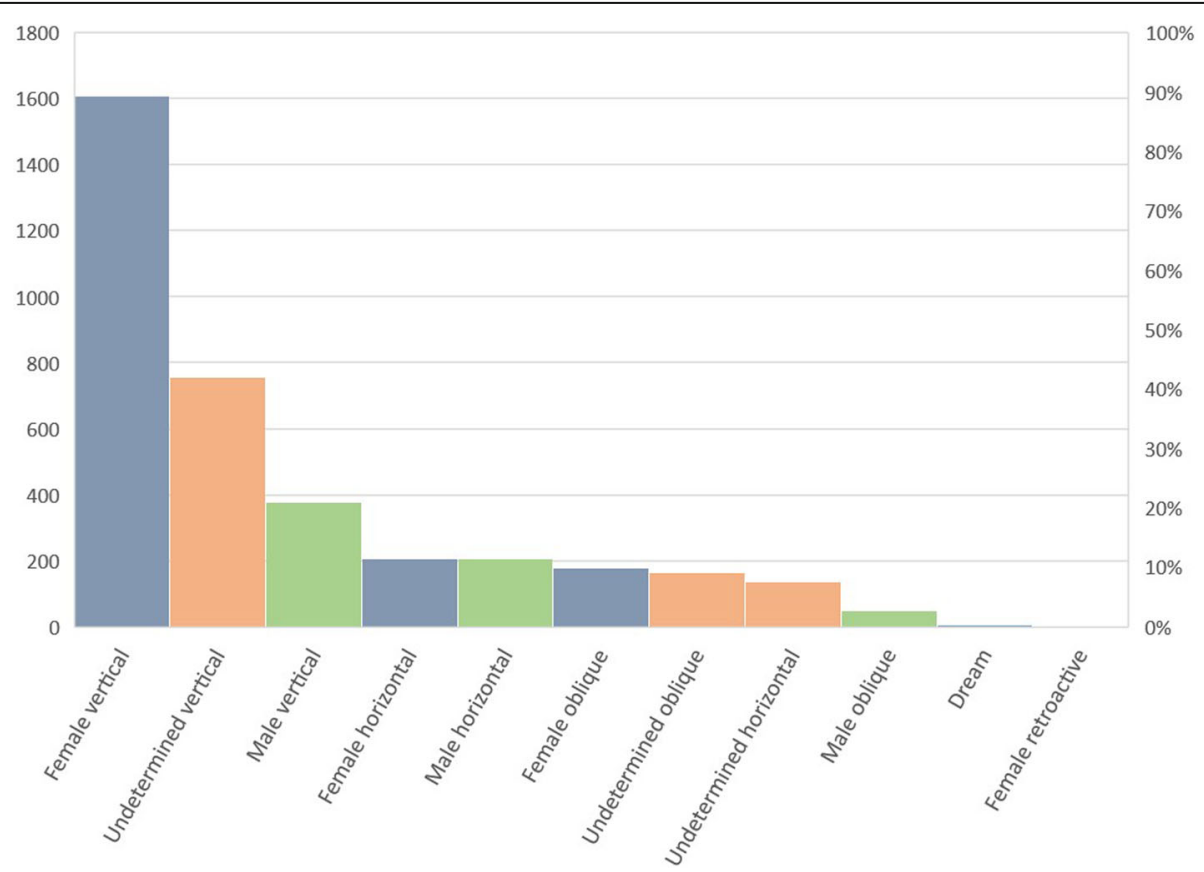

Fig. 5 Proportion of the different types of transmission of herbal medicine knowledge on the French Guiana coast (URs and \%) 


\section{Discussion: distant influences as factors of a gradual interculturalization People interviewed}

Our sampling takes into account the different sociodemographic components of the French Guianese society, in terms of age, gender, sectors of activity, and ethnicity. However, the important cultural diversity of French Guiana leads to a large number of smaller subgroups whose number of people interviewed is sometimes insufficient to further analyze, with significant results, medicinal uses instead of species.

Moreover, the number of French Guianese Créoles interviewed may seem relatively disproportionate compared to the other groups present. Despite the fact that this group is still one of the most numerous minority (as counting for less than $50 \%$ of the overall population), it certainly reflects the importance of the creolization process which still seems to operate in French Guiana [42].

\section{Botany}

A large number of the medicinal plants cited are cultivated, often as food or aromatic plants. To become popular, in addition to their intrinsic or supposed therapeutic properties, medicinal plants often need to be abundant and easily accessible [43-46]. Among the main botanical families cited in our study, several are also known to contain weeds (Asteraceae, Lamiaceae, Poaceae, Verbenaceae...), confirming this trend.

\section{Do plants travel with people, or people with plants?}

As true as humans travel, plants do the same. Many medicinal plants have become, over time, "globalized plants" [47], marketed and consumed worldwide, even far from their areas of origin [48, 49]. As our study also shows, today's pharmacopeias are therefore very globalized, containing many pantropical species. According to the "versatility theory" $[50,51]$, these are often species whose wide distribution seems linked to their primary use as ornamental plants $[50,52]$ or food [50, 52-55]. In addition, migrants who often already have a familiar relationship with these species in their country of origin continue to use them preferentially when they find them during their transnational movements, as has already been highlighted in several ethnobiological studies [3, 5, 9, 11]. But traveling plants may sometimes become invasive species, despite their medicinal properties $[45,46]$. Indeed, according to the availability theory $[46,51,56$, 57], many medicinal plants are selected as such above all because they are abundant. Thus, this study also shows the weight of some invasive exotic species in French Guiana. If from an ecological point of view the arrival in a new environment of invasive species is unanimously recognized as negative for local biodiversity [58, 59], from a cultural point of view, on the other hand, more and more authors suggest taking into account the perception that local populations have of these species, particularly when they benefit of these species [58, 60-67]. The example of Melaleuca quinquenervia in French Guiana illustrates well this latter idea and shows how socially constructed the status of an "invasive" species can be, and remains extremely relative from a cultural point of view. Native to eastern Australia and presumably introduced in French Guiana during the middle of the twentieth century for the production of paper pulp [68], the species largely colonized the herbaceous savannas of the coast of French Guiana and tends today to extend in the east of Suriname. Conservationists perceive it as a "serious ecological problem" and recommend "to eradicate it absolutely" [69]. However, the Ndjuka populations of the Maroni basin have widely adopted it as a first-class medicinal species, thanks to its appreciated menthol scent (they call it fekisi uwii, literally "Vicks@ leaves") and its abundant dissemination which is perceived as "a blessing."

\section{Cross-culturalism}

As the intense cross-culturalism observed in the uses of the medicinal flora seems to show, intercultural exchanges are present and might eventually lead to a relative homogenization of phytotherapy practices. Very often, this pattern is reinforced by a "visualization process" effect [2] that could be assimilated to an "oblique" type transmission [43]. Overall, this result shows how questionable it seems for a community to appropriate the use of a particular plant, these being in most cases transversal to several cultural groups.

\section{Divergences and specificities}

The observed fluxes of medicinal plant-related knowledge are also different in nature according to the groups. In accordance with the theory of "centrality" developed by Hopkins [70], the groups that are the most integrated into exchange networks are also those that are most inclined to intercultural exchange through interaction with other cultural communities. Milliken and Albert [71] also argue in this sense that the level of phytotherapeutic knowledge depends on the degree and nature of contact between neighboring socio-cultural groups and, in Guyana, van Andel et al. [72] show that the Arawak, having "a longer history of contact with the urban areas," cite more exotic species than the Karib populations from the interior. In French Guiana, our observations therefore seem to confirm this trend: recent migrants (Haitians, Surinamese Creoles, Brazilians), less integrated in these interethnic contemporary exchange 
networks, cite generally a lower number of use reports (Table 1) and especially cite fewer local species. For example, the Amazonian Bignoniaceae species Mansoa alliacea, generally widely used in medico-magic remedies [39], is not used by any of the migrant communities while it is widely used among Amerindian, Maroon, and French Guianese Creole groups. One can however estimate, as postulated by Abreu et al .[21], that the children of migrants will in turn show a more hybrid knowledge, made of both knowledge acquired locally and knowledge specific to their group of origin and transmitted by their parents. This is undoubtedly what explains the high number of use reports of the St Lucian community (Table 1), which seems to have gathered over several generations very diversified uses thanks to multiple learning favored by a prolonged contact with the indigenous populations subsequent to the first gold rushes [73]. In addition, we can legitimately assume that this "gradual interculturalization" is also multilateral: migrant communities integrate over time by assimilating local customs but also by contributing to the pharmacopeias evolution through the introduction of new species and practices.

\section{Access strategies and transmission}

The level of knowledge around medicinal plants seems favored by migratory contributions, and this even in the city, as already observed by Tareau et al. $[16,17]$ or by van Andel et al. [74]. Indeed, if the artificialization of rural spaces and the sedentarization of urban populations can appear as a major obstacle to the perpetuation of phytotherapy practices and knowledge [75], we note however that in average, levels of knowledge appear in French Guiana roughly similar among urban and nonurban residents. This result might be explained by two different ways. On the one hand, it is certainly linked to the fact that a large part of the urban dwellers being of recent rural origin (immigration, rural exodus), the link with nature seems stronger and is for the moment probably maintained in the city in some segments of the population, in which the phytotherapy practices still constitutes an inexpensive alternative to biomedicine and a strong identity marker $[16,17]$. On the other hand, even in densely populated areas, contact with nature is still possible in the cities of French Guiana: people go picking on the Cayenne forested hills, in the "Malgaches' forest" in St. Laurent, or in urban wastelands [17]. We were also able to show that many plants came from outside French Guiana along the migration process, which is consistent with the "relocalization" sub-process of ethnobotanical hybridizations described by Ladio and Albuquerque [22]. The influence of the Caribbean and bordering countries, from where a large part of the French Guianese population originates, is clearly highlighted here, showing the constructive role that migration plays on the evolution of the composition of the pharmacopeias. As observed elsewhere [5, 7, 76], migrant communities continue to use cultural keystone species, which are esteemed species (and products) that are firmly rooted in their original therapeutic traditions, relocating plants and practices in their country of settlement. In accordance with the previous observations of Tareau et al. [28], this phenomenon is particularly intense in "tinctorial" border areas which thus act as important zones of influence with regard to local populations.

This study once again highlights the predominant place of women in the transmission of ethnobotanical knowledge, in accordance with the literature [16, 7783]. Our results are in line with other ethnobiological works which have shown that vertical and intra-cultural transmission constitutes the main mode of transmission of biological knowledge in many societies [43, 84-86]. This mode of transmission can also be considered more ethnocentric [87], favoring a certain compartmentalization of practices and a largely identical reproduction of parental practices by the following generations.

\section{Conclusion}

Finally, what emerges from this study is above all that the multicultural context, characterized by significant migratory flows, generates a complex, polymorphous, and always dynamic medicinal flora. The pharmacopeias are continually enriched with new species and uses coming from diverse horizons, and each cultural group's medicinal floras seem to overlap while sharing, in the same time, a number of common features. Indeed, behind a shared facade, strong cultural specificities nevertheless stand out through the existence of culturally indicative species. Nevertheless, this study is only based on the citations of species counted for each of the cultural groups, which hides another diversity of distinct medicinal uses.

The transmission of knowledge of herbal medicine, mainly feminine and intra-cultural, initially promotes a compartmentalization of knowledge and uses, which end up spreading over time, but in a differentiated way depending on the nature and the intensity of exchanges between communities. The relative centrality of some groups in intercultural exchanges therefore seems to be an important explanatory factor in the conservation or progressive erasing of culturally marked practices.

However, the context of interculturalism undeniably fosters continuous changes in herbal medicine practices. New plants and uses appear (or disappear) thanks to the movements and contacts of populations, perpetually 
redrawing the contours of dynamic pharmacopeias, built upon multiple and permanent influences. It would be interesting to go even further in this type of study by trying to understand how these changes operate at the scale of several generations, operating either a gradual leveling of intercultural knowledge or, on the contrary, maintaining a compartmentalization over time.

\section{Acknowledgements}

We must warmly thank all the 205 persons who accepted to answer patiently to the interviews realized during the fieldwork.

\section{Authors' contributions}

MAT collected the field data. MAT, GO, and MP conceptualized the study and analyzed the field data. GO and MAT performed the botanical identifications and drafted the manuscript. $A B$ contributed to the realization of the statistical analyzes. MAT, GO, and MP participated in discussing the manuscript. All authors have read and approved the final manuscript.

\section{Funding}

This work was supported by "Investissement d'Avenir" grants managed by the French Agence Nationale de la Recherche (Labex DRIIHM/IRDHEl and Labex CEBA: ANR-10-LABX-25-01). M.-A. Tareau received a PhD grant from the Université de Guyane and a grant from the Rotary Club of Rémire-Montjoly (French Guiana).

\section{Availability of data and materials}

Plants collected are deposited in the Cayenne IRD herbarium (CAY), under the voucher numbers MAT 01 to MAT 510. Interview data and consent forms are stored at the Laboratoire Ecologie, Evolutions, Interactions des Systèmes Amazoniens (LEEISA), Centre de Recherche de Montabo, Cayenne, French Guiana. The data contained in this paper is presented with more details in Tareau's PhD dissertation [29].

\section{Ethics approval and consent to participate}

Prior to the implementation of the French transcription of the Nagoya protocol, and in the absence of internal ethics committee at the Université de Guyane, we worked in accordance with the recommendations of the Code of Ethics of the International Society of Ethnobiology. Informed consent forms were given to all the respondents in order to present and explain to them clearly the objectives of this research project and to obtain their signed agreement to participate. Each of the interviewees was informed beforehand of the confidentiality of this study, and of his/her right to withdraw its participation at any time, and of the objective of publication at the end under the form of a PhD thesis and scientific publications.

\section{Consent for publication}

This manuscript does not contain any individual person's data, and further consent for publication is not required.

\section{Competing interests}

The authors declare that they have no competing interests.

\section{Author details}

'LEEISA (Laboratoire Ecologie, Evolution, Interactions des Systèmes Amazoniens), CNRS, Université de Guyane, IFREMER, 97300 Cayenne, French Guiana. ${ }^{2}$ Cayenne, French Guiana.

Received: 31 May 2020 Accepted: 27 August 2020

Published online: 16 September 2020

\section{References}

1. Ladio AH, Acosta M. Urban medicinal plant use: do migrant and nonmigrant populations have similar hybridisation processes? J Ethnopharmacol. 2019

2. Hurrell JA, Pochettino ML. Urban ethnobotany: theoretical and methodological contributions. In: Albuquerque UP, da Cunha LVF C, De Lucena RFP, RRN A, editors. Methods and techniques in ethnobiology and ethnoecology: Springer; 2014. p. 293-309. Available from: http://link. springer.com/10.1007/978-1-4614-8636-7_18.

3. Kujawska M, Pieroni A. Plants used as food and medicine by Polish migrants in Misiones, Argentina. Ecol Food Nutr. 2015;54:255-79.

4. van Andel T, Westers P. Why Surinamese migrants in the Netherlands continue to use medicinal herbs from their home country. J

Ethnopharmacol. 2010;127:694-701.

5. Vandebroek I, Balick MJ, Yukes J, Durán L, Kronenberg F, Wade C, et al. Use of medicinal plants by Dominican immigrants in New York City for the treatment of common health conditions. A comparative analysis with literature data from the Dominican Republic. Traveling cultures and plants The Ethnobiology and Ethnopharmacy of human migrations Studies in environmental Anthropology and Ethnobiology. 2007;7:39-63.

6. Pieroni A, Sheikh Q-Z, Ali W, Torry B. Traditional medicines used by Pakistani migrants from Mirpur living in Bradford, Northern England. Complement Therapies Med. 2008;16:81-6.

7. Volpato G, Godínez D, Beyra A. Migration and ethnobotanical practices: the case of tifey among Haitian immigrants in Cuba. Hum Ecol. 2009;37:43-53.

8. van Andel TR, van't Klooster C. Medicinal plant use by surinamese immigrants in Amsterdam, the Netherlands. Travelling Cultures Plants. 2007; 7:122-44.

9. Ceuterick M, Vandebroek I, Torry B, Pieroni A. Cross-cultural adaptation in urban ethnobotany: the Colombian folk pharmacopoeia in London. J Ethnopharmacol. 2008;120:342-59.

10. Nguyen MLT. Comparison of food plant knowledge between urban Vietnamese living in Vietnam and in Hawai'i. Econ Bot. 2003;57:472-80.

11. Waldstein A. Mexican migrant ethnopharmacology: pharmacopoeia, classification of medicines and explanations of efficacy. J Ethnopharmacol. 2006;108:299-310.

12. Kujawska M, Hilgert NI. Phytotherapy of Polish migrants in Misiones, Argentina: legacy and acquired plant species. J Ethnopharmacol. 2014;153: 810-30.

13. de Medeiros PM, Soldati GT, Alencar NL, Vandebroek I, Pieroni A, Hanazaki $\mathrm{N}$, et al. The use of medicinal plants by migrant people: adaptation, maintenance, and replacement. Evid Based Complement Alternat Med. 2012; Available from: https://www.hindawi.com/journals/ecam/2012/ 807452/abs/.

14. Balick MJ, Lee R. Looking within: urban ethnomedicine and ethnobotany. Altern Ther Health Med. 2001;7:114-5.

15. Emery MR, Hurley PT. Ethnobiology in the city: embracing the urban ecological moment. J Ethnobiol. 2016;36:807-19.

16. Tareau MA, Palisse M, Odonne G. As vivid as a weed... Medicinal and cosmetic plant uses amongst the urban youth in French Guiana. J Ethnopharmacol. 2017;203:200-13.

17. Tareau M-A, Dejouhanet L, Odonne G, Palisse M, Ansoe C. Wild medicinal plant collection in transitional societies: a case analysis from French Guiana. EchoGéo. 2019; Available from: http://journals.openedition.org/echogeo/1 7260 .

18. Almada ED. Urban socio-biodiversity: ethnoecology of Cities. 5(1):1-8.

19. Júnior WSF, Santoro FR, Vandebroek I, Albuquerque UP. Urbanization, modernization, and nature knowledge. In: Albuquerque UP, Nóbrega Alves RR, editors. Introduction to ethnobiology [Internet]. Cham: Springer International Publishing: 2016. p. 251-6.

20. Vandebroek I. Intercultural health and ethnobotany: how to improve healthcare for underserved and minority communities? J Ethnopharmacol. 2013;148:746-54.

21. Abreu DB de O, Santoro FR, Albuquerque UP de, Ladio AH, Medeiros PM de. Medicinal plant knowledge in a context of cultural pluralism: a case study in Northeastern Brazil. J Ethnopharmacol 2015; 175: 124-130.

22. Ladio AH, Albuquerque UP. The concept of hybridization and its contribution to urban ethnobiology. Ethnobiol Conserv. 2014:1-9.

23. de Medeiros PM, Albuquerque UP, de Oliveira Abreu DB, da Silva TC, Ferreira Junior WS, Ramos MA, et al. What drives the use of natural products for medicinal purposes in the context of cultural pluralism? Eur J Integ Med. 2016;8:471-7

24. Nascimento ALB, Medeiros PM, Albuquerque UP. Factors in hybridization of local medical systems: simultaneous use of medicinal plants and modern medicine in Northeast Brazil. PLoS One. 2018;13:e0206190.

25. Pieroni A, Quave CL, Giusti ME, Papp N. "We are Italians!": the hybrid ethnobotany of a Venetian diaspora in Eastern Romania. Hum Ecol. 2012;40: 435-51. 
26. Piantoni F. Migrants en Guyane. Actes Sud. 2011.

27. Alby S, Léglise I. Le paysage sociolinguistique de la Guyane. Ibis Rouge Editions, 2007.

28. Tareau M-A. Circulations et échanges de plantes et de savoirs phytomédicinaux sur la frontière franco-brésilienne. Revue Française sur la Santé et les Territoires, 2019.

29. Tareau M-A. Mixed pharmacopeias in French Guiana: ethnobotany of a phytotherapy in motion [PhD]: Université de la Guyane; 2019. Available from: https://hal.archives-ouvertes.fr/tel-02452873.

30. Noy C. Sampling knowledge: the hermeneutics of snowball sampling in qualitative research. International Journal of Social Research Methodology. Routledge. 2008;11:327-44.

31. SoE. Available from: https://ethnobiology.org/about-society-ethnobiology/ ethics.

32. Heinrich M, Edwards S, Moerman DE, Leonti M. Ethnopharmacological field studies: a critical assessment of their conceptual basis and methods. J Ethnopharmacol. 2009:124:1-17.

33. Phillips O, Gentry AH. The useful plants of Tambopata, Peru: II. Additional hypothesis testing in quantitative ethnobotany. Econ Bot. 1993;47:33-43.

34. Team RC. R Core Team (2017). R: a language and environment for statistical computing. R Found Stat Comput Vienna, Austria URL http://www R-project org/, page R Foundation for Statistical Computing. 2017;

35. Roberts DW, Roberts MDW. Package 'labdsv.' Ordination and Multivariate. 2016;

36. Oksanen J, Kindt R, Legendre P, O'Hara B, Stevens MHH, Oksanen MJ, et al The vegan package. Comm Ecol Pack. 2007;10:631-7.

37. The Angiosperm Phylogeny Group. An update of the Angiosperm Phylogeny Group classification for the orders and families of flowering plants: APG IV. Bot J Linn Soc. 2016;181:1-20.

38. Heckel É. Les plantes médicinales et toxiques de la guyane française : catalogue raisonné et alphabétique ([Reprod.]) / par le Dr Edouard Heckel [Internet]. Protat frères (Macon); 1897 . Available from: http://gallica.bnf.fr/ ark:/12148/bpt6k98264j.

39. Grenand P, Moretti C, Jacquemain H, Prévost M-F. Pharmacopées traditionnelles en Guyane : créoles, wayãpi, palikur. IRD Editions. IRD Editions, 2004

40. Garibaldi A, Turner N. Cultural keystone species: implications for ecological conservation and restoration. Ecology and Society [Internet]. 2004;9. Available from: https://www.ecologyandsociety.org/vol9/iss3/art1/inline. html\#species.

41. Lorenzi H, Matos FJ. Plantas medicinais no Brasil: nativas e exóticas; 2002.

42. Jolivet M-J. La créolisation en Guyane: Un paradigme pour une anthropologie de la modernité créole (Creolization in French Guiana: a paradigm for an anthropology of Creole Modernity). Cahiers d'études africaines. 1997;37:813-37.

43. Leonti M. The future is written: impact of scripts on the cognition, selection, knowledge and transmission of medicinal plant use and its implications for ethnobotany and ethnopharmacology. J Ethnopharmacol. 2011;134:542-55.

44. Odonne G, Houël E, Bourdy G, Stien D. Treating leishmaniasis in Amazonia: a review of ethnomedicinal concepts and pharmaco-chemical analysis of traditional treatments to inspire modern phytotherapies. J Ethnopharmacol. 2017;199:211-30.

45. Stepp JR, Moerman DE. The importance of weeds in ethnopharmacology. J Ethnopharmacol. 2001;75:19-23.

46. Voeks RA. Disturbance pharmacopoeias: medicine and myth from the humid tropics. Ann Assoc Am Geogr. 2004:94:868-88.

47. Beaufort B. La fabrique des plantes globales : une géographie de la mondialisation des végétaux du Nouveau Monde et particulièrement de I'Amazonie [Internet] [phdthesis]. Université Sorbonne Paris Cité; 2017. Available from: https://tel.archives-ouvertes.fr/tel-01773066/document.

48. Ferrão J e M. Le Voyage des plantes et les grandes découvertes. Chandeigne; 2015.

49. Grenand P, Prévost M-F, Fleury M. Le voyage discret des plantes. Revue d'ethnoécologie. 2012 ; Available from: https://ethnoecologie.revues.org/733.

50. Alencar NL, de Sousa Araújo TA, de Amorim ELC, de Albuquerque UP. The inclusion and selection of medicinal plants in traditional pharmacopoeias-evidence in support of the diversification hypothesis. Econ Bot. 2010;64:68-79.

51. Gaoue OG, Coe MA, Bond M, Hart G, Seyler BC, McMillen H. Theories and major hypotheses in ethnobotany. Econ Bot. 2017;71:269-87.

52. Benett B, Prance G. Introduced plants in the indigenous pharmacopeias of the northern South America. Econ Bot. 2000;1:90-102.
53. Etkin NL. Edible medicines: an ethnopharmacology of food by Nina L. Etkin: The University of Arizona Press; 2008

54. Torres-Avilez W, Méndez-González M, Durán-García R, Boulogne I, Germosén-Robineau L. Medicinal plant knowledge in Caribbean Basin: a comparative study of Afrocaribbean, Amerindian and Mestizo communities. J Ethnobiol Ethnomed. 2015;11:18-29.

55. Vandebroek I, Balick MJ. Lime for chest congestion, bitter orange for diabetes: foods as medicines in the Dominican community in New York City. Econ Bot. 2014;68:177-89.

56. Albuquerque UP, Lucena RF, Monteiro JM, Florentino AT. Cecília de Fátima CBR. Evaluating two quantitative ethnobotanical techniques. Ethnobot Res Appl. 2006;4:051-60.

57. Soldati GT, Albuquerque UP. A new application for the optimal foraging theory: the extraction of medicinal plants. Evidence-based complementary and alternative medicine. 2012, article ID: 364564.

58. Davis MA, Chew MK, Hobbs RJ, Lugo AE, Ewel JJ, Vermeij GJ, et al. Don't judge species on their origins. Nature. 2011:474:153.

59. Kairo M, Ali B, Cheesman O, Haysom K, Murphy S. Invasive species threats in the Caribbean Region. Arlington: Report to the Nature Conservancy; 2003.

60. Coates P. American perceptions of immigrant and invasive species: strangers on the land: Univ of California Press; 2007.

61. dos Santos LL, do Nascimento ALB, Vieira FJ, da Silva VA, Voeks R, Albuquerque UP. The cultural value of invasive species: a case study from semi-arid Northeastern Brazil. Econ Bot. 2014;68:283-300.

62. Hurrell JA, Delucchi G. Aportes de la Etnobotánica al estudio de las invasiones biológicas. Casos en la región rioplatense (Argentina). 2013; Available from: http://ri.conicet.gov.ar/handle/11336/53847.

63. Marshall NA, Friedel M, van Klinken RD, Grice AC. Considering the social dimension of invasive species: the case of buffel grass. Environ Sci Pol. 2011; 14:327-38.

64. Medeiros PM. Why is change feared? Exotic species in traditional pharmacopoeias. Ethnobiol Conserv. 2013;2(3):6-11.

65. Pfeiffer JM, Voeks RA. Biological invasions and biocultural diversity: linking ecological and cultural systems. Environ Conserv. 2008;35:281-93.

66. Pochettino ML, Hurrell JA, Lema VS. Local botanical knowledge and agrobiodiversity: homegardens at rural and periurban contexts in Argentina. Horticulture. IntechOpen; 2012.

67. Stepp JR, Wyndham FS, Zarger RK. Ethnobiology and biocultural diversity: Proceedings of the Seventh International Congress of Ethnobiology: University of Georgia Press; 2002.

68. Stier A, de Carvalho WD, Rostain S, Catzeflis F, Claessens O, Dewynter M, et al. The Amazonian savannas of French Guiana: cultural and social importance, biodiversity, and conservation challenges: Tropical Conservation Science. 2020; Available from: https://journals.sagepub.com/doi/10.1177/194 0082919900471

69. Léotard G, Chaline O. Inventaire et cartographie de la répartition des espèces végétales invasives en Guyane française : rapport d'étude. Guyane: DEAL; 2013.

70. Hopkins A. Use of network centrality measures to explain individual levels of herbal remedy cultural competence among the Yucatec Maya in Tabi, Mexico. Field Methods. 2011;23:307-28.

71. Milliken W, Albert B. The use of medicinal plants by the Yanomami Indians of Brazil, part II. Econ Bot. 1997;51:264-78.

72. van Andel TR. Non-timber forest products of the North-West District of Guyana: Utrecht University; 2000.

73. Stroebel M-B. Les gens de l'or. Plon; 2019

74. van Andel T, Carvalheiro LG. Why urban citizens in developing countries use traditional medicines: the case of Suriname. Evid Based Complement Alternat Med. 2013:2013:1-13.

75. Fleury M. Transmission du savoir et modernité en Guyane française : les savoirs traditionnels sont-ils condamnés? Des sources du savoir aux médicaments du futur. IRD Editions, 2002.

76. Vandebroek I, Balick MJ, Ososki A, Kronenberg F, Yukes J, Wade C, et al. The importance of botellas and other plant mixtures in Dominican traditional medicine. J Ethnopharmacol. 2010;128:20-41.

77. Albuquerque UP, Soldati GT, Sieber SS, Ramos MA, de Sá JC, de Souza LC. The use of plants in the medical system of the Fulni-ô people (NE Brazil): a perspective on age and gender. J Ethnopharmacol. 2011;133:866-73.

78. Hewlett BS, Cavalli-Sforza LL. Cultural transmission among Aka pygmies. Am Anthropol. 1986;88:922-34 
79. Lozada M, Ladio A, Weigandt M. Cultural transmission of ethnobotanical knowledge in a rural community of northwestern Patagonia, Argentina. Econ Bot. 2006;60:374-85.

80. Quinlan MB, Quinlan RJ. Modernization and medicinal plant knowledge in a Caribbean horticultural village. Med Anthropol Q. 2007;21:169-92.

81. Torres-Avilez W, Medeiros PM de, Albuquerque UP. Effect of gender on the knowledge of medicinal plants: systematic review and meta-analysis. Evidence-Based Complementary and Alternative Medicine. 2016, article ID: 6592363.

82. Voeks RA. Are women reservoirs of knowledge? Gender, ethnobotany and globalization in northeast Brazil. Singap J Trop Geogr. 2007;28:7-20.

83. Voeks RA, Leony A. Forgetting the forest: assessing medicinal plant erosion in eastern Brazil. Econ Bot. 2004;58:294-306.

84. Hewlett B, DeSilvestri A, Guglielmino CR. Semes and genes in Africa. Curr Anthropol. 2002:43:313-21.

85. Reyes-García V, Broesch J, Calvet-Mir L, Fuentes-Peláez N, McDade TW, Parsa $\mathrm{S}$, et al. Cultural transmission of ethnobotanical knowledge and skills: an empirical analysis from an Amerindian society. Evol Hum Behav. 2009;30: 274-85.

86. Zarger RK. Acquisition and transmission of subsistence knowledge by Q'eqchi'Maya in Belize. In: Stepp JR, Wyndham FS, Zarger RK, editors. Ethnobiology and Biocultural Diversity pp 592-603. USA: International Society of Ethnobiology; 2002.

87. Boyd R, Borgerhoff-Mulder M, Durham WH, Richerson PJ. Are cultural phylogenies possible? In: Weingart P, editor. Human by nature: between biology and the social sciences: Taylor and Francis; 1997. p. 355-84.

\section{Publisher's Note}

Springer Nature remains neutral with regard to jurisdictional claims in published maps and institutional affiliations.

Ready to submit your research? Choose BMC and benefit from:

- fast, convenient online submission

- thorough peer review by experienced researchers in your field

- rapid publication on acceptance

- support for research data, including large and complex data types

- gold Open Access which fosters wider collaboration and increased citations

- maximum visibility for your research: over $100 \mathrm{M}$ website views per year

At $\mathrm{BMC}$, research is always in progress.

Learn more biomedcentral.com/submissions 